Article

\title{
Sex Trafficking at the Border: An Exploration of Anti-Trafficking Efforts in the Pacific Northwest
}

\author{
Alexander Norfolk ${ }^{1, *}$ and Helga Hallgrimsdottir ${ }^{2}$ \\ 1 Centre for Global Studies, University of Victoria, Victoria, BC V8P5C2, Canada \\ 2 School of Public Administration, University of Victoria, Victoria, BC V8W2Y2, Canada; hkbenedi@uvic.ca \\ * Correspondence: anorfolk@uvic.ca
}

Received: 8 March 2019; Accepted: 10 May 2019; Published: 17 May 2019

\begin{abstract}
The prevalence of human trafficking for the purposes of sexual exploitation and forced labour in the Pacific Northwest has been well documented in recent years. This paper focuses specifically on trafficking for sex work across the British Columbia and Washington State border and seeks to determine whether the border is an effective instrument or tool for the identification and intervention of human trafficking for sex work. We provide an exploration of the legal frameworks and policies on either side of the border and offer an analysis of the cross-border anti-trafficking efforts carried out at the borderlands. The paper concludes that current mechanisms fail to appropriately address and combat the issue of cross-border sex trafficking for several reasons, including the following: a lack of uniform definitions of sex trafficking; the conflation of migrant sex work and sex trafficking, leading to misidentification at the border; and an emphasis on border security measures over victim support. Recommendations for enhanced responses are provided.
\end{abstract}

Keywords: sex trafficking; cross-border security; Pacific Northwest

\section{Introduction}

Few human rights issues have captured the attention of the North American population in the twenty-first century like human trafficking has. The exploitation of human beings, whether it be for labour or sex, has given rise to a myriad of campaigns spearheaded by federal, municipal, and non-profit institutions in both Canada and the United States. This surge in interest was generated, in large part, by the development of the United Nations Protocol to Prevent, Suppress, and Punish Trafficking in Persons in 2000 (UN Protocol), which called for states to increase efforts to fight the problem within their own countries.

The UN Protocol defines human trafficking quite broadly as the act of maintaining control over an individual through force, fraud, or coercion, in order to exploit them (UN Protocol 2000; Peters 2015). This exploitation can manifest itself in various forms, including "the exploitation of the prostitution of others or other forms sexual exploitation, forced labour or services, slavery or practices similar to slavery, servitude or the removal of organs" (UN Protocol 2000).

Regional law enforcement and government agencies in Canada and the United States have recently been engaged in developing interventions and policing strategies to address the prevalence of human trafficking for the purposes of sexual exploitation and forced labour (RCMP 2010, 2013; Washington State Task Force against the Trafficking in Persons 2008). This paper will focus specifically on trafficking for sex work (or, sex trafficking) in the Pacific Northwest, which includes thirteen separate ports of entry between Canada and the United States. Through an analysis of the region's current anti-trafficking efforts and policies, the paper examines how the border is deployed in these interventions, and whether the border is indeed an effective instrument or tool for the identification and intervention of human trafficking for sex work. 
The first section addresses border theory and the Pacific Northwest border, followed by a section on definitions and terminology surrounding the complex issue of trafficking. A brief overview of sex trafficking in British Columbia (BC) and Washington State is then provided, along with an exploration of the legal frameworks and policies that are in place on either side of the border. The final sections provide an exploration and analysis of the responses to sex trafficking at the BC-Washington border. We conclude with recommendations for enhanced responses.

Research for this paper was based on secondary data largely consisting of peer-reviewed articles, books, and reports from government agencies and various non-profit organizations; much of the information was found through online journal databases, the library at the University of Victoria, and official government websites. Web and library searches contained the key words 'sex trafficking', 'migrant sex work', 'cross-border security', and 'Pacific Northwest'. The authors reviewed more than 80 documents over an eight-month research period. Primary qualitative research fell beyond the scope of this study, which presented a significant limitation. It is challenging to discuss such an urgent and important subject without directly consulting those affected by it; we acknowledge the need for extensive primary investigation to be conducted in this area, and we hope that the information and recommendations provided in the pages below will lead to further examination of-and response to-these pressing issues.

\section{The Pacific Northwest Border}

Borders are often defined by the ways in which individuals utilize them; for some, a border exists to be enforced, for others, it is a space of connection or transaction, and for others still, it exists as a barrier or obstruction. This notion is explored by Espanol et al. (2018), who contend that borders are imbued with 'meaning' for those who interact with them. For vulnerable or marginalized individuals such as migrant sex workers, refugees, or new immigrants, the act of crossing the border can often be fraught with unpleasant emotions or experiences, and thus the border may take on negative meaning for these individuals. Border authorities, on the other hand, uphold laws and restrictions while using the tools at their disposal to 'systematically sort' border crossers (Pickering and Ham 2013); for these agencies, a border becomes a space for enforcing territorial power and ordering "interactions between members of social groups" (Paasi 2009, p. 217).

The meanings that dominant agencies bestow upon borders turn into rules for crossing them. Paasi (2009) posits that law enforcement and ordering at the border is "based on societal power relations", providing "the ultimate grounds for the regional transformation and re-scaling of social and spatial relations" (Paasi 2009, p. 217). Part of this transformation or re-scaling may manifest as deeper integration between bordering states.

The concepts of 'regional transformation and re-scaling of social and spatial relations' are evident in US-Canada bordering processes. In their discussion of border culture and borderlands theory, Konrad and Nicol (2011) write that the US-Canada border and the surrounding areas have "become places for sharing-a 'transactional space'" (p. 76); they maintain that, over the years, the borderland separating the US and Canada has developed into an area of interaction, integration, and cooperation. Scholars have long noted the economic, social, cultural, and political integration that exists throughout the Pacific Northwest cross-border region in particular. Susan Clarke (2000), in her article on the politics of ideas and economic development in Cascadia, posits that the area has become what she calls a "symbolic regime" where governance strategies "extend beyond individual communities and ... across borders" (p. 360).

Shared cultural, ideological, and political values have led to closer cross-border integration on issues regarding regional policy and governance. Brunet-Jailly $(2008,2012)$ contends that increasing economic interdependence among areas of the Pacific Northwest (particularly along the Vancouver-Seattle geographic corridor) is paving the way for 'policy parallelism' and strengthened collaboration between governments. Brunet-Jailly (2008) notes that the convergence of social and cultural values, along with increased institutional development at the border, have contributed to this integration. This augmented 
integration can often result in multiple state actors working together to address a cross-border need or issue. It is important to note here as well that the kinds of cross-border collaborations, networks, and institutions that emerge here are grounded in regional practice and are relatively insulated from the vagaries of federal politics. Thus, even as Canada and the United States seem to be shifting further apart ideologically under the Trump administration, this has not resulted in cooler relations between the provinces and states of the Pacific Northwest, and indeed these regions are continuing to pursue various strategies that will further integrate border management, including, for example, pre-clearance infrastructure investments on both sides of the border (Storer et al. 2015). Seen from this perspective, the border is equally a site of convergence and policy parallelism as it is a dividing line and entryway between the two nations. Thus, even though we understand borders to be the site at which trafficking can be controlled and policed, practices at the border are also constitutive of policy and law around trafficking on both sides of the border.

\section{Definitions and Legal Framing of Sex Trafficking}

The collection of accurate data about the prevalence of human trafficking in North America is significantly impeded by a lack of conceptual clarity, in particular, as pertains to how to distinguish between human trafficking and smuggling, and how human trafficking for sex work is distinct from migrant sex work (Aradau 2003; Farrell and Fahy 2009). As we discuss below, legal definitions of human trafficking are expansive and are thus sensitive to political and legal agendas of policymakers and politicians. On the other hand, it is important to note that it may not always be easy to draw clear lines between these categories when it comes to describing the lived experiences of individuals.

\subsection{Definitions and Terminology}

The following summary of human trafficking is presented in Article Three of the UN Protocol (2000, Article 3):

'Trafficking in persons' shall mean the recruitment, transportation, transfer, harbouring or receipt of persons, by means of the threat or use of force or other forms of coercion, of abduction, of fraud, of deception, of the abuse of power or of a position of vulnerability or of the giving or receiving of payments or benefits to achieve the consent of a person having control over another person, for the purpose of exploitation. Exploitation shall include, at a minimum, the exploitation of the prostitution of others or other forms of sexual exploitation, forced labour or services, slavery or practices similar to slavery, servitude or the removal of organs.

It is useful to note some of the keywords used in the above definition, namely: force, fraud, and coercion. These words or their synonyms are present in both the Canadian and American legal descriptions of trafficking. Consider this section of Canada's Criminal Code provided by the Canadian Department of Justice (2016):

Trafficking in persons is about exploitation and does not necessarily involve movement. For the purpose of the trafficking offences, the Criminal Code states that a person exploits another person if they: cause someone to provide, or offer to provide, labour or a service by engaging in conduct that, in all the circumstances, could reasonably be expected to cause the other person to believe that their safety or the safety of a person known to them would be threatened if they failed to provide, or offer to provide, the labour or service.

Instead of including the words 'force', 'fraud', or 'coercion' in this description, the Canadian Criminal Code emphasizes the means by which force or coercion can occur, i.e., the overarching threat to the individual's safety. It is also worth noting that the description here makes it clear that the act of human trafficking need not involve movement. For comparison, the Washington State Criminal Code uses the following definition (Washington State Legislature 2013): 
(1) A person is guilty of trafficking in the first degree when:

(a) Such person:

(i) Recruits, harbors, transports, transfers, provides, obtains, buys, purchases, or receives by any means another person knowing, or in reckless disregard of the fact, (A) that force, fraud, or coercion ... will be used to cause the person to engage in:

(I) Forced labor;

(II) Involuntary servitude;

(III) A sexually explicit act; or

(IV) A commercial sex act, or (B) that the person has not attained the age of eighteen years and is caused to engage in a sexually explicit act or a commercial sex act.

The Victims of Trafficking and Violence Protection Act (TVPA), drafted and signed into United States law in 2000, addresses sex trafficking specifically, placing it under the banner of 'severe forms of trafficking'. Again, the terms force, fraud, and coercion remain key to the definition, and are distinguishing features of what constitutes a trafficking crime:

The term "severe forms of trafficking in persons" means:

(a) sex trafficking in which a commercial sex act is induced by force, fraud, or coercion, or in which the person induced to perform such act has not attained 18 years of age; or

(b) the recruitment, harbouring, transportation, provision, or obtaining of a person for labour services, through the use of force, fraud, or coercion for the purpose of subjection to involuntary servitude, peonage, debt bondage, or slavery.

Drawing on the above definitions, this paper defines sex trafficking as an act of maintaining control of an individual through the use of force, fraud, or coercion for the purposes of sexual exploitation. With this simplified definition, we aim to break the characterization of sex trafficking down into its fundamental properties so that it can be deployed easily throughout discussions of both US and Canadian contexts. Scholars have frequently noted the difficulty in producing international uniform definitions of sex trafficking and human trafficking in general, an issue that is highlighted later in this paper.

Human smuggling versus human trafficking: Foreign nationals who pay to be willingly transported into Canada or the US are not victims of trafficking, as they have willingly acquired the services of a third party to assist them in crossing the border, and the transaction ends once they enter the country; in other words, smuggling does not necessarily involve the exploitation of one individual by another (McAdam 2013; RCMP 2010). However, it is also important to note that smuggling, like human trafficking, involves highly vulnerable individuals, and that a smuggling transaction may become a trafficking situation (Miller and Baumeister 2013, p. 28).

Sex trafficking versus migrant sex work: The legal definitions of trafficking provided here make a distinction between forced and voluntary labour. However, several studies have noted that the conflation of voluntary migrant sex work with sex trafficking continues to be an issue with regards to legal frameworks and public perceptions in Canada and the US (Augustin 2006; Capous Desyllas 2007; Pickering and Ham 2013).

Kempadoo (2015) has noted that beliefs and social narratives about human trafficking have been more significant to the development of interventions into trafficking than empirical evidence. In turn, these narratives have dual roots in abolitionist feminist scholarship and conservative social commentary, in which any engagement in sex work is presumed to be coercive and all sex workers are victims (Kempadoo 2015). These perspectives have been criticized for stripping agency from sex workers. In addition, as detailed further below, it is possible that this attention to human trafficking as a social problem may, in fact, increase the vulnerability of sex workers, particularly migrant sex workers (Doezema 1999; Pickering and Ham 2013).

In North America (as in many other parts of the world), sex trafficking is frequently tied to migrant sex work. Weitzer (2007) argues that a 'moral crusade' against sex work has been influential 
in establishing anti-sex work laws on both sides of the border, forcing those who engage voluntarily in sex work to face tougher restrictions and to experience increased vulnerability to sex trafficking. In her article on how ideology shapes policy with regards to trafficking, Ditmore (2015) states that, "historically, trafficking in persons has been equated with prostitution" (p. 108). This conflation of sex trafficking with sex work continues today, and has been well documented in recent years (see Augustin 2006; Chuang 2010; Corvid 2014; Jackson 2016; Jeffrey 2005; Pickering and Ham 2013). Over the past decade, neo-abolitionists in North America have lobbied to criminalize all forms of sex work, arguing that sex work (including migrant sex work) is tantamount to sex trafficking regardless of context and individual circumstances (Augustin 2006; Chuang 2010).

Migrant sex workers migrate (within nations and across nations) to work in various sectors of the sex industry, including on the streets, in exotic dance clubs, and massage parlours (Jeffrey 2005; Kapur 2003; Migrant Sex Workers Project n.d.; RCMP 2013; Schwartz 2014). Contrary to many conservative or abolitionist narratives, migrant sex workers who voluntarily choose to work in the sex industry do not perceive themselves as 'victims' in need of saving; indeed, a large proportion of individuals who engage in this work want to be recognized as professionals providing a legitimate service (Ferris 2015). Many individuals who self-identify as consensual migrant sex workers continue to lobby for the legalization and destigmatization of sex work (Brownstone 2015; Ferris 2015). An individual at the poverty line who migrates to sell sex as a means of providing support to his/her family would not necessarily be considered a victim or a voluntary sex worker, as the 'choice' to engage in sex work was made as a result of personal circumstance. However, as Jeffrey (2005) explains, "even if entry into the trade was a less-than-perfect option, it does not mean that, once in the trade, women do not define their interests as making as much money as possible in the safest environment possible, and that these interests should be ignored as false consciousness" (p. 34). A number of academics have noted that the treatment of all sex workers simply as victims is highly problematic; as Jeffrey (2005) explains, linking sex work to sex trafficking "justifies paternalist and criminalizing approaches to the sex-trade, which fail to provide sex-workers with the decent working conditions that they have been demanding" (p. 34). Others have posited that painting migrant sex workers and actual victims of sex trafficking with the same brush robs voluntary sex workers of personal agency, characterizing them as helpless victims rather than working professionals (Brown 2016; Corvid 2014; Jackson 2016).

Scholars have taken further issue with this victim/voluntary professional binary. Peters (2015) contends that participation in the sex industry should instead be viewed on a continuum, with sex trafficking on one end, and voluntary, professional sex work on the other. Included on this continuum are those individuals who may not have initially chosen this line of work, but who continue to make a living from it, as well as instances where the level of force, fraud, or coercion exerted on an individual is difficult to determine.

\subsection{Legal Framing in Canada and the United States}

There are some notable differences between Canada and the United States in terms of overall policy regimes and legal framings. There is significantly more independence between state and federal judiciaries in the United States than there is in Canada. The 2013 Supreme Court of Canada decision to strike down as unconstitutional laws against prostitution, and the subsequent introduction of laws that criminalized clients a year later immediately changed the legal landscape for sex work across all of Canada. This is not true in the United States, where there is significantly more variation across states in how sex work laws are enacted.

In Washington State, prostitution is a misdemeanor under state law, and "a person is guilty of prostitution if such person engages or agrees or offers to engage in sexual conduct with another person in return for a fee" (WA Legislature, RCW 9A.88.030). Promoting prostitution (i.e., profiting from, or soliciting customers for, sex workers) is considered a felony, and "patronizing a prostitute" is considered a misdemeanor, while other forms of sex work, such as pornography and exotic dancing are legal in the state. (WA Legislature, RCW 9A.88.070; RCW 9A.88.080; RCW 9A.88.110). On the other 
hand, punishments for trafficking in persons range in severity and are largely dependent on the nature and extent of each individual crime. In Canada, convicted traffickers have faced sentences ranging from two to 41 years of incarceration (Perrin 2010b; RCMP 2010). Penalties for trafficking in the US also vary, but a conviction of engaging in sex trafficking of a minor (under the age of 14), for instance, carries a punishment of 15 years to life imprisonment (US Department of Justice 2015).

The Protection of Communities and Exploited Persons Act (or, Bill C-36), introduced in Canada in 2014, specifically targets 'pimps' and clients rather than sex workers themselves (Canadian Public Health Association 2014; Hon Chu and Glass 2013; McIntyre 2015; Perrin 2014; Schwartz 2014). As such, this Act closely resembles the so-called 'Nordic Model' of addressing sex work, which decriminalizes the act of selling sex but "criminalizes the purchase of sex" (Hon Chu and Glass 2013, p. 101). Although regarded by some as a progressive step forward, many sex workers argue that instead of offering protection, this approach tends to "force outdoor sex workers to engage in rushed encounters, increase the likelihood of coercion, and push outdoor sex workers into secluded, unsafe locations" (Canadian Public Health Association 2014, p. 7).

In 2000, the US State Department introduced The Victims of Trafficking and Violence Protection Act (TVPA) (US Department of State 2000). The TVPA criminalizes the act of forcing individuals into exploitative labour situations. The TVPA strengthens law enforcement to reduce violence against women, and provides more comprehensive services to victims of violence (US Department of State 2000). The TVPA has been reauthorized several times since its inception and has been followed by several further legislative acts addressing the problem of trafficking in the United States (US Department of Homeland Security 2015). Canada has taken similar steps to combat trafficking, creating the Immigration and Refugee Protection Act (IRPA) in 2001 (Government of Canada 2016a; Oxman-Martinez et al. 2005), passing a number of laws against trafficking from 2005 onward, and developing the nation's first and only Office to Combat Trafficking in Persons (OCTIP) in British Columbia in 2007 (Barrett 2010; British Columbia Ministry of Justice 2013).

Introduced alongside the TVPA, the T-visa provides protection to foreign victims of trafficking by granting temporary non-immigrant status in the country for up to four years (US Citizenship and Immigration Services 2011). As stated by US Citizenship and Immigration Services (2011), to be eligible for a T-visa an individual must have been a victim of a trafficking crime, must prove that they "would suffer extreme hardship involving unusual and severe harm if [they] were removed from the United States", and must be willing to "comply with any reasonable request from a law enforcement agency for assistance in the investigation or prosecution of human trafficking" (para. 5). In 2001, the Canadian government adopted a similar approach as part of the IRPA; Temporary Resident Permits (TRPs) are issued to foreign individuals in Canada who have been victims of a trafficking crime and who are unable to return to their country of origin. In contrast to the T-visa, the TRP does not require victims to collaborate with law enforcement or testify against their traffickers (Government of Canada 2016c).

At the regional level, the BC and Washington State governments have identified combating human trafficking as a priority. Washington was the first state in the US to create a law criminalizing human trafficking, and the state has maintained a human trafficking Task Force since 2002, the first in the country (Gozdziak and Collett 2005; Kohl-Welles 2012; Washington State Task Force against the Trafficking in Persons 2008). In 2013, the British Columbia Ministry of Justice put forth a three-year Action Plan to combat human trafficking in the province, focusing primarily on sexual exploitation of youth and within Indigenous communities, as well as labour exploitation of vulnerable workers (British Columbia Ministry of Justice 2013). ${ }^{1}$ In conjunction with the Action Plan, the provincial government

1 The plan identified the following five priority areas to address in an effort to curb trafficking in the region: (1) raise awareness and increase public understanding of human trafficking in BC; (2) Increase the number of service providers and frontline personnel with training on human trafficking; (3) Empower and build capacity in local BC communities (including Indigenous communities) to prevent human trafficking and provide assistance to trafficked persons; (4) Increase coordination of services to address the unique needs of trafficked persons in B.C. communities, emphasizing culturally 
launched a series of free online anti-trafficking training modules aimed at service providers and first responders who may come into contact with victims of trafficking (OCTIP 2014).

Individual politicians within $\mathrm{BC}$ and Washington have recently increased their efforts to fight human trafficking. The work of Washington State Senate member Maralyn Chase, for instance, was instrumental in ensuring the passing of a 2015 bill (Senate Resolution 8644) to support the reduction of trafficking in the state (Washington State Legislature 2015). In BC, Minister of Justice Suzanne Anton has been working in conjunction with OCTIP to deliver the province's three-year Action Plan to Combat Human Trafficking (British Columbia Ministry of Justice 2015).

\section{The State of Knowledge on Sex Trafficking in the Pacific Northwest}

This section briefly overviews the current state of knowledge with regards to sex trafficking in the Pacific Northwest. We recognize that, due to the complex and clandestine nature of this crime, available data is often incomplete and subject to dispute. Moreover, any discussion of statistical information concerning sex trafficking must also address the lack of nuance in quoting numbers and fact-based generalizations. Reports provided by government or law enforcement agencies often do not specify how data was collected, nor do they acknowledge the diverse experiences and circumstances of those affected by sex trafficking; in particular, it is not clear to what extent the data collected includes individuals who would self-identify as a migrant sex worker, as opposed to a trafficked individual (Pickering and Ham 2013). The following paragraphs thus offer a limited 'snapshot' of the situation, with a focus on the knowledge that is available to policymakers.

Thirteen international border crossings dot the 687 kilometre stretch of land that separates Washington State and British Columbia; of these 13 crossings, the four that serve the area surrounding Vancouver and Seattle are the busiest in the region (British Columbia Ministry of Transportation and Infrastructure 2016). These four crossings have been the focus of significant attention from researchers, government officials, and law enforcement agencies (Perrin 2010a; United States-Canada 2006).

Available policy documents on trafficking, include the 2006 Bi-national Assessment of Trafficking in Persons, the 2016 US Department of State Trafficking in Persons (TIP) Report, the Washington State Task Force against the Trafficking in Persons (2008) as well as reports from the RCMP (2010, 2013), and The Genesis Project (2013). These documents identify the entry points used to transport victims into the US from Canada, including land ports, airports, marine ports, and "less monitored areas between ports of entry" (United States-Canada 2006, p. 9), and demographic characteristics. In British Columbia, women and girls who are of Indigenous descent are identified as particularly vulnerable to these crimes (Canadian Public Health Association 2014; Sethi 2007). Foreign victims in this region have been known to come from areas of Eastern Europe, Asia, and Africa (RCMP 2010; Washington State Task Force against the Trafficking in Persons 2008). A number of reports have stated that victims of trafficking in BC and Washington tend to be in their 20's and 30's, however many are much younger (Pham 2012; RCMP 2010). Several sources claim that children as young as 12 and 13 have been victims of sex trafficking in the area (Pham 2012; RCMP 2010, 2013; The Genesis Project 2013) and that individuals who engage in sex trafficking activities generally target vulnerable girls and women, such as at-risk youth, runaways, new immigrants, or victims of domestic violence (US Department of State 2016).

A report released by the RCMP in 2010 indicated that many sex trafficking victims are foreign migrant workers who either enter Canada or the US legally, or they are migrants who pay to be smuggled in illegally, but are then coerced into forced sex work soon after they arrive (RCMP 2010). This switch from legal immigrant or irregular migrant upon entry, to trafficked victim once entered, is a large part of what makes trafficking victims so difficult to identify.

appropriate responses; and (5) Increase research, policy and legislative responses to human trafficking in BC (British Columbia Ministry of Justice 2013). The third-year status report of the Action Plan, released in September 2016, details some of the key initiatives taken by OCTIP and other organizations and service providers throughout the province (British Columbia Ministry of Justice 2015). 
Other scholars have noted that Canada has been used as a transit country through which traffickers funnel victims. For instance, Benjamin Perrin (2010a) claims that from 1996 up until 2010, a total of 1336 "potential South Korean victims" were trafficked through Canada to the US, most of whom were women "destined for sexual exploitation" in various cities, including New York, Los Angeles, San Francisco and Seattle (p. 25). Citing a 1997 US Human Rights report, Young (1998) points to a case in which three young Canadian women were forced into sex work in Vancouver, "where they earned money to pay for their passage to the United States"; when these young girls entered the US, they were taken to work in the sex industry in California, Hawaii, and Washington (pp. 78-79). The 2006 Bi-national Assessment of Trafficking in Persons also confirms Canada as a transit country, estimating that 1500 to 2200 victims are trafficked through Canada, into the US each year (United States-Canada 2006).

The RCMP (2010) reports that perpetrators of sex trafficking in the region tend to be males aged 19 to 32, however, females "are increasingly becoming involved in human trafficking" (p. 11). Research suggests that individuals who engage in sex trafficking crimes often "have a history of early exposure to sexual abuse, violence, drug use, and family or community connection to prostitution" (Pham 2012, p. 19). Scholars have noted that traffickers 'recruit' their victims through multiple forms of deception, fostering trust by posing as boyfriends or legitimate employers (Perrin 2010b; Sethi 2007; The Genesis Project 2013). While 'recruiting' the victim, traffickers may give gifts and expensive clothing to the individual, the cost of which ends up turning into debt for the victim to repay through forced work (British Columbia Ministry of Justice 2013). Perpetrators of sex trafficking are often reported to have used websites such as Craigslist or other internet classifieds to recruit their victims (Green 2016; RCMP 2010).

The Washington State Task Force Against the Trafficking in Persons (Washington State Task Force against the Trafficking in Persons 2008) states that individuals who engage in trafficking exert tight control over their victims, often keeping them hidden or disguised, or moving them frequently. Tactics of violence and drug addiction are reportedly used to control victims and force them to engage in sex work (British Columbia Ministry of Justice 2013). Perpetrators of trafficking have been known to withhold foreign victims' documentation, passports, or legal paperwork in order to maintain control over them (Washington State Task Force against the Trafficking in Persons 2008; Young 1998). Law enforcement in BC and Washington generally conduct reactive investigations, relying on the cooperation and testimony of the victim. Because victims are often silenced with threats of violence or may fear deportation and arrest, investigations may fall short of prosecuting the criminal operations or individuals responsible for exploiting the victims (Barrett 2010; McDonald 2014; Perrin 2010b; RCMP 2010; Sethi 2007; Washington State Task Force against the Trafficking in Persons 2008).

The following two notable examples are among the very few regional domestic sex trafficking arrests and convictions in recent years. In November 2015, a BC man named Reza Moazami was sentenced to 23 years in prison on charges of human trafficking. He was convicted of forcing 11 girls, between 14 to 19 years old, into prostitution in Vancouver. Mr. Moazami used tactics "ranging from coercion and intimidation to humiliation and outright violence to ensure they continued to make money for him" (National Post 2015). This was the first human trafficking conviction in BC under the Criminal Code (Porter 2016, April 19, personal communication). More recently, in early 2016, a joint operation between the Seattle police force and the King County Sheriff's Office led to the arrest of 13 individuals running a brothel in which "prostituted women from South Korea were forced to work often for $12 \mathrm{~h}$ a day, seven days a week, to pay off debts" (Green 2016).

\section{Responses to Sex Trafficking at the Border}

As a demarcated point where individuals are first observed by authorities and "systematically sorted" (Pickering and Ham 2013), the border has the potential to be a crucial place for the identification of trafficking and trafficked victims, and for developing effective responses to the problem. In ratifying the 2000 UN Trafficking Protocol, the United States and Canada agreed to adhere to each of the 20 Articles within the document, including Article 11, which holds that "Parties shall strengthen, to the extent possible, such border controls as may be necessary to prevent and detect trafficking in persons", 
and that "Parties shall consider strengthening cooperation among border control agencies by, inter alia, establishing and maintaining direct channels of communication" (pp. 6-7). In the wake of 9/11, the measures taken by Canada and the US to curb trafficking were immediately eclipsed by the further steps each nation took to tighten border security and reinforce controls on immigration (Oxman-Martinez et al. 2005).

\subsection{Cross-Border Efforts to Combat Trafficking}

Recent cooperation between Canada and the US has resulted in the adoption of several important bilateral agreements to increase security at the border, all of which are indicative of high levels of cross-border collaboration as well as policy parallelism. Following 11 September 2001, Canada and the US have worked bilaterally to develop new restrictions with regards to border crossing, "particularly for refugees and individuals from countries that the United States has identified as linked to threats of terrorism" (Oxman-Martinez et al. 2005, p. 12). The 2001 Canada-US Smart Border Declaration and the 2002 Safe Third Country Agreement on Refugees are examples of such reforms, both of which call for higher instances of deportation, harsher penalties for those found using false documents, and regular detention of migrants who cannot prove their identities satisfactorily (IRPA 2001; Oxman-Martinez et al. 2005). In 2011, Canada and the US initiated the Beyond the Border (BTB) Action Plan, a long-term partnership which seeks to augment "collective security and accelerate the flow of legitimate goods, services, and people, both at and beyond the border" (Government of Canada 2015).

Integrated Border Enforcement Teams (IBETs) were formed in 2002, comprising of representatives from the RCMP, Canada Border Services Agency (CBSA), the Office of Border Patrol, US Department of Homeland Security, US Immigration and Customs Enforcement, and the US Coast Guard (Williamson 2009). As stated in the United States-Canada 2006 Bi-national Assessment of Trafficking in Persons, the "IBETs are designed to enhance border integrity and security along the shared Canadian-US border by identifying, investigating and interdicting persons and organizations that pose a threat to national security, or are engaged in organized criminal activity, such as [trafficking in persons], illegal migration, smuggling of drugs or other goods, and terrorism" (p. 19).

Integrated Border Intelligence Teams (IBITs) complement the IBETs by "collecting, analyzing and disseminating tactical, investigative and strategic intelligence information pertaining to cross border crime between the United States and Canada" (United States-Canada 2006, p. 19). On the US side of the border, unmanned aerial drones are used to survey remote areas of borderland, providing video to IBITs for analysis (Perrin 2010c). Although Public Safety Canada (2015b) notes that the IBETs and IBITs have been successful in intercepting cross-border smuggling networks, details regarding their success in combating human trafficking were not readily accessible.

In a further move to enhance Canada-US border security, the RCMP and US Coast Guard worked together to introduce Integrated Cross-Border Maritime Law Enforcement Operations (ICMLEO) in 2012 (Government of Canada 2016b). This agreement, also known as Shiprider, enables specially trained RCMP officers to work on board US Coast Guard vessels within US territory, and vice versa. As explained by the RCMP, the Shiprider program "removes the international maritime boundary as a barrier to law enforcement by enabling seamless continuity of enforcement and security operations across the border" (RCMP 2015, para. 5). Shiprider operations cover a total of 250 kilometres of the shared Canada-US maritime border in the Pacific region and, as of 2013, the Shiprider program consists of 83 cross-designated officers (Government of Canada 2015). At the time of writing this paper, we did not find any publicly released information regarding how effective Shiprider has been in identifying and intercepting cross-border trafficking cases.

Formed in 1997, the Canada-United States Cross-Border Crime Forum (CBCF) holds regular joint meetings involving senior law enforcement and justice officials from various organizations in Canada and the US. The forum "addresses transnational crime issues such as organized crime, counter-terrorism, smuggling, economic crime, and other emerging cross-border threats" (Public Safety Canada 2015a). A report on topics addressed at this year's forum has yet to be released. 
Adopted in 2011, the Entry/Exit Initiative is an agreement between Canada and the US to "exchange biographic entry information on third-country nationals (non-US or -Canadian citizens), permanent residents of Canada who are not US citizens and lawful permanent residents of the US who are not Canadian citizens at land ports of entry" (CBSA 2016). This information sharing system allows law enforcement officials from both countries to collect the following data elements: first name, middle name, last name, date of birth, nationality, gender, document type, document number, document country of issuance, work location code/US POE codes, date of entry, and time of entry (CBSA 2013). In March 2016, the Canadian and US governments "reaffirmed the commitment to a coordinated entry and exit information system and pledged to build upon the process already in place" (CBSA 2016); one significant outcome of this reaffirmation has been the introduction of legislation allowing the CBSA "to collect routine biographic information on all travellers exiting Canada" in addition to those entering the country (CBSA 2016).

As mentioned earlier, Canada has been identified as a 'transit country' for sex trafficking (Perrin 2010a; 2010c). It has been reported that trafficking cases involving the use of Canada as a transit country is due, in large part, to the country's immigration laws and visa waiver program (Oxman-Martinez et al. 2005; Perrin 2010c). In particular, some have argued that the lack of visa requirements for South Korean nationals travelling to Canada has been a major draw for traffickers wishing to transport South Korean victims through Canada and overland into the US (Perrin 2010a, 2010c; United States-Canada 2006). In early 2016, however, the Canadian government announced a new system that requires all foreign nationals travelling under the visa waiver program to apply for an Electronic Travel Authorization (eTA) before travelling to the country (Citizenship and Immigration Canada Newsletter 2016).

Similar to the Electronic System for Travel Authorization (ESTA) in the US, the eTA system allows border officials to screen travellers for admissibility before they arrive at a Canadian port of entry (Government of Canada n.d.; US Customs and Border Protection 2016). It is as yet unclear whether the implementation of the eTA system, used in concert with the ESTA, will have an effect on traffickers' use of Canada as a transit country. Some scholars have posited that the eTA/ESTA system will not necessarily make it easier to identify trafficked individuals, as there is no way of knowing who will or will not be a victim prior to their arrival in the destination country (Perrin 2010a, 2010c).

The formation of IBETs and IBITs, the Shiprider agreement, the establishment of the Entry/Exit Initiative, and the eTA/ESTA system, all exemplify successful cooperation across the Canada-US border, giving credence to the concept of policy parallelism. Brunet-Jailly (2008) suggests that close political linkages such as these have the potential to develop "parallel solutions to common problems" (p. 114). However, as will be demonstrated in the following section of this paper, the collaboration that currently exists in the Pacific Northwest border region has not necessarily resulted in a more effective or comprehensive response to the issue of sex trafficking specifically.

\subsection{Analysis of Border Mechanisms}

So far, there has been limited reporting on the success of the abovementioned cooperative reforms in tackling the issue of sex trafficking and human trafficking in general. Perrin (2010b) notes that specific detailed information on how effective these measures have been in combating human trafficking in the region is sparse; law enforcement agencies such as the RCMP's Human Trafficking National Coordination Centre, the US Human Smuggling and Trafficking Centre, and US Immigration and Customs Enforcement are reportedly "unwilling to discuss any details of their joint efforts" (Perrin 2010b, p. 183). It is due to this lack of transparency that anti-trafficking efforts remain difficult to evaluate.

Scholars suggest that increased security at the Canada-US border has driven the human trafficking and smuggling trade deeper underground, making migrants more vulnerable to abuse and violence on both sides of the border (Kapur 2015). Such activities have been further criticized by others for denying human and labour rights to migrants. Oxman-Martinez et al. (2005) posit that under these reforms, individuals "seeking entry to Canada are first seen through a security lens before a compassionate or humanitarian lens" (p. 13). Moreover, the cross-border collection and sharing of biographic information 
has been bolstered by the use of expanded surveillance technology, such as unmanned aerial vehicles, or drones (Finn and Wright 2012; Molnar and Parsons 2016). The intensification of surveillance of travellers-whether they are crossing the border legally or with criminal intent-can amount to an infringement on human rights depending on the degree to which information is collected and acted upon. As Finn and Wright (2012) posit, these heightened surveillance mechanisms perpetuate social sorting by race, class, gender, and sexuality at the border, disproportionately targeting "already marginalised populations" and impinging on their safety and civil liberties (pp. 189-91).

In recent years, provincial and state governments in BC and Washington have independently increased their efforts to directly respond to human trafficking by establishing anti-trafficking enforcement teams (BC's OCTIP, and the Washington State Task Force Against the Trafficking of Persons) and, in the case of BC, launching a three-year Action Plan to combat trafficking. Although the actions taken by these two regional governments have been heralded as significant and necessary steps in the fight against trafficking, it is the lack of communication and alignment between BC and Washington law enforcement at the border that remains an issue.

One way this lack of communication manifests itself is in the multiple and vague definitions used, particularly with regard to sex trafficking. Legal definitions in both the US and Canada have remained fairly broad so as to encompass all forms of sex trafficking, but this has led to frequent "inconsistencies in victim identification," causing law enforcement and border officials to be subjective in their responses to the crime (Peters 2015, p. 82). The sweeping language used to describe sex trafficking in the TVPA, IRPA, and in the Criminal Codes of both BC and Washington, creates space for law enforcement officials on either side of the border to interpret sex trafficking differently (Peters 2015). Although all definitions use the terms 'force', 'fraud', and 'coercion' (or synonyms), the lack of a uniform definition which is shared and agreed upon by law enforcement agencies on both sides of the border is problematic. As Peters (2015) asserts, "the multilayered law on the books leads to complexities in how the law is envisioned in the minds of those implementing it, resulting in uneven consequences for victims" (p. 70).

Further compounding the absence of specificity and analogous definitions in the law, trafficking can be extremely difficult to clearly identify at the border and, very often, border officials are tasked with spotting the potential for a sex trafficking crime to occur rather than the crime itself (Ham et al. 2013; McAdam 2013; Miller and Baumeister 2013). The nature of trafficking is such that the exploitation of an individual being trafficked across the border is rarely visible at the border. Traffickers take precautions to hide themselves, and exploitative acts that involve force, fraud, or coercion most often occur at the source or destination site rather than during the migration process (Aromaa 2007; Perrin 2010a, 2010c; Pickering and Ham 2013). For example, a victim at the border might be in possession of valid documentation and an entry visa, and they may not necessarily appear to be frightened or in any type of distress. In such instances, it is possible that victims may have been coached by their trafficker(s) on how to act, or that an individual may have been brought or lured into the country on false promises of legitimate employment, unaware that they are destined to be exploited (Perrin 2010a, 2010b).

Peters (2015) notes that the ways in which law officials and border agents approach potential trafficking cases tends to be moulded by their previous experiences with trafficking crimes, and their own preconceived ideas of what sex trafficking looks like. In their 2013 study of the role of borders in identifying sex trafficking, authors Pickering and Ham found that "despite the sophistication of surveillance technologies [at the border], risk assessments ... ultimately rely on officers' judgements about the clothing women wore and what this signified about their sexual risk" (p. 12). The subjective identification of trafficking activity can potentially lead to the wrongful prosecution of migrant sex workers in some cases, or could perhaps enable those actually involved in a trafficking crime to elude law enforcement at the border. Underlying this subjective identification of sex trafficking at the border are the ideologies and morality judgements that can often influence assessments. The ongoing stigmatization of sex work and the tendency to conflate migrant sex work with sex trafficking can often have damaging consequences for individuals crossing the border. 
Examining the legal responses to sex work on either side of the Canada-US border can help to explain the responses that each country has toward migrant sex workers crossing the border. In her discussion of Canada's treatment of migrant sex workers, Jeffrey (2005) posits that existing legal frameworks essentially regard migrant sex workers entering Canada as "a foreign policy problem, not a national problem", thereby allowing "the government to argue for tighter security measures, particularly in border controls and policing, in order to protect women-measures which only penalize migrants and makes them more vulnerable to abuse" (pp. 42-43).

Studies have pointed to the adoption of the T-visa for foreign victims of trafficking in the US to illustrate how the government's anti-trafficking efforts prioritize prosecution over protection and prevention. Capous Desyllas (2007) holds that the T-visa and its eligibility requirements place "the burden of proof on the migrant to 'prove her innocence' and 'coercion'", and to assist in the arrest and conviction of the trafficker(s) (pp. 67-68). The reliance on non-citizen victim testimonies, and the process of determining whether the victim's narrative indicates that a trafficking crime has occurred can be fraught with complications; many victims have difficulty recounting events due to the traumatic nature of the crime, and many remain silent due to shame or fear of reprisals by the trafficker (Peters 2015).

For migrants who have been trafficked into or between the US and Canada, eliciting a reliable testimony from them can be problematic, as they may not speak the language, they may be distrustful of government or law enforcement agencies, or believe they may be deported (McDonald 2014). Furthermore, Wetmore (2003) argues that placing the onus on the victim to prove they would suffer 'extreme hardship' and 'unusual and severe harm' if they returned home is too high a standard, and one that most individuals will find unattainable. She adds that foreign "trafficking victims should no longer be treated as illegal aliens first and foremost, and the T-visa does not take the victims far enough away from that characterization" (Wetmore 2003, p. 176).

Taking these challenges into consideration, we propose that heightened collaboration and communication mechanisms between Canada and US border agencies, and between BC and Washington border officials and anti-trafficking teams, could create a vastly enhanced cross-border anti-trafficking system. Several strategies for improvement are recommended below.

\section{Recommendations}

We contend that the following six activities must be implemented for the BC-Washington border to be an effective tool for identifying human trafficking for sex work:

\subsection{Align Definitions of Sex Trafficking and Distinguish It from Sex Work}

The definition of sex trafficking, and of what constitutes a sex trafficking crime, must be agreed upon by law enforcement along the Canada-US border. Particular effort must be made to distinguish sex trafficking from migrant sex work, and to avoid conflating the two distinct terms.

\subsection{Increase Anti-Trafficking Training for Border Officials and Increase Public Awareness in Communities Near the Border}

As this paper has demonstrated, border security officials often lack the tools necessary to properly identify sex trafficking at the border. In order to be as proficient as possible in recognizing potential sex trafficking crimes, members of the CBSA and the US Border Patrol must engage in regular, up-to-date training programs that focus specifically on sex trafficking and accurate victim identification. Additional joint training and capacity building sessions that include officials on both sides of the BC-Washington border would serve to bolster anti-trafficking efforts significantly.

Moreover, local government and service providers in BC and Washington should work to increase public awareness about human trafficking in border areas along the BC-Washington border, particularly in cities or towns that are located close to any of the 13 designated border crossings. The same effort must be taken to deliver trafficking awareness to Indigenous groups in the region. 
6.3. Open Channels of Communication between OCTIP and the Washington State Task Force and Renew BC's Action Plan, Identifying Cross-Border Collaboration as a Priority Area

In conducting research for this paper, we did not find evidence to suggest that OCTIP and the Washington State Task Force Against the Trafficking of Persons had made efforts to liaise with each other, or that either office had devised channels for the sharing of information and intelligence. Although neither organization operates specifically at the border, establishing an open line of communication between the two offices would help to build a stronger cross-border partnership in the Pacific Northwest. Enhanced information flows would encourage the exchange of smart practices and could facilitate more efficient cross-border anti-trafficking investigations.

The OCTIP-led three-year Action Plan to Combat Human Trafficking reached its end in 2016. As at the time of writing, no commitment has been made by the BC government or OCTIP to renew the plan. The final report on the Action Plan, released in September 2016, states only that human trafficking in BC will continue to be addressed by the Community Safety and Crime Prevention Branch as part of its violence against women program (British Columbia Ministry of Public Safety and Solicitor General 2016). It is important that the BC government and OCTIP renew the Action Plan, and we recommend that cross-border collaboration — specifically with Washington State—-be an added priority area.

\subsection{Establish Uniform Data Collection Mechanisms for Cross-Border Trafficking in the BC-Washington Region and Conduct an Official Evaluation of Bilateral Efforts}

Just as trafficking terminology and definitions must be uniform across the border, so must be the mechanisms for collecting data. This would provide clear and shared data on human trafficking activity along the BC-Washington border, allowing for a more efficient response to trafficking in the region. Local governments in $\mathrm{BC}$ and Washington should also work together to conduct an evaluation of recent bilateral anti-trafficking activities in the Pacific Northwest. A report of the findings should be produced and used to improve cross-border collaboration.

\subsection{Lower Eligibility Requirements for the T-Visa}

To fully protect the rights of trafficking victims, and to provide appropriate services and supports to these individuals, the eligibility requirements for the T visa in the US must be softened significantly. As mentioned above, trafficking victims are often unable to meet the high standards set out by US policy. We recommend that US requirements for victims of trafficking to receive temporary residency be aligned with Canadian TRP standards.

\subsection{Decriminalize Sex Work and Solicitation of Sex Workers on Both Sides of the Border}

As indicated in this paper, the current legal framing of sex work in Canada and the US denies sex workers of certain rights and services and forces them to work in unsafe locations, thereby increasing their vulnerability to dangers such as sex trafficking.

\section{Conclusions and Suggestions for Further Research}

Sex trafficking continues to be an incredibly complex and difficult issue to address in North America. Over the past decade and a half, Canada and the United States have taken major steps to combat this crime, adopting numerous policies and bilateral programs aimed at increasing national security and stemming international cross-border trafficking. With a specific focus on the Pacific Northwest regions of British Columbia and Washington State, this paper has demonstrated that the current cross-border efforts to fight sex trafficking in the region face significant challenges in providing effective responses to the issue.

We conclude that current mechanisms fail to appropriately address and combat the issue of cross-border sex trafficking for several reasons, including a lack of uniform definitions of sex trafficking; the conflation of migrant sex work and sex trafficking, leading to misidentification at the border; and an 
emphasis on border security measures over victim support. An exploration and analysis of these challenges has enabled us to provide several promising strategies which, if implemented, will serve to effectively target sex trafficking at the border. We contend that deeper collaboration between federal, state, and provincial agencies will allow for an enhanced cross-border response to this widespread yet clandestine crime. At the same time, policy responses to this issue should be attentive to the history of cross-border collaboration and policy parallelism in this region. The recommendations provided in this paper seek to further advance policy parallelism in the Pacific Northwest to effectively strengthen the region's response to sex trafficking. In particular, we note that paying attention to shared legal and conceptual definitions of sex trafficking, establishing uniform data collection mechanisms, and harmonizing the legal framework around sex work, would form significant steps towards both enhancing enforcement of anti-sex trafficking laws and protecting those that are vulnerable to being trafficked. Normative and legal shifts on one side of the border can, and should, become triggers for better enforcement practices.

Further research is required to develop a more comprehensive evaluation of current cross-border anti-trafficking efforts and data collection mechanisms in this region. Primary research consisting of interviews and/or focus groups with individual border officials will a support deeper understanding of the varying attitudes toward, and perceptions of, sex trafficking and sex workers at borderlands.

Author Contributions: A.N. conducted the research and wrote the manuscript. H.H. conceived of the topic, supervised the research, and supported manuscript revisions.

Funding: This research was funded by the Social Sciences and Humanities Research Council grant number 895-2012-1022.

Conflicts of Interest: The authors declare no conflict of interest.

\section{Glossary of Terms}

$\begin{array}{ll}\text { BC } & \text { British Columbia } \\ \text { BTB } & \text { Beyond the Border Action Plan } \\ \text { CBCF } & \text { Cross-border Crime Forum } \\ \text { CBSA } & \text { Canada Border Services Agency } \\ \text { CPHA } & \text { Canadian Public Health Association } \\ \text { ESTA } & \text { Electronic System for Travel Authorization } \\ \text { eTA } & \text { Electronic Travel Authorization } \\ \text { IBETs } & \text { Integrated Border Enforcement Teams } \\ \text { IBITs } & \text { Integrated Border Intelligence Teams } \\ \text { ICMLEO } & \text { Integrated Cross-border Maritime Law Enforcement Operations/Shiprider } \\ \text { IRCC } & \text { Immigration, Refugees and Citizenship Canada } \\ \text { IRPA } & \text { Immigration and Refugee Protection Act } \\ \text { OCTIP } & \text { Office to Combat Trafficking in Persons } \\ \text { RCMP } & \text { Royal Canadian Mounted Police } \\ \text { TRP } & \text { Temporary Resident Permit } \\ \text { T-Visa } & \text { Temporary Non-Immigrant Status Visa } \\ \text { TVPA } & \text { Victims of Trafficking and Violence Protection Act } \\ \text { UN Protocol } & \text { The UN Protocol to Prevent, Suppress and Punish Trafficking in Persons } \\ \text { WA } & \text { Washington State } \\ \text { WHO } & \text { World Health Organization }\end{array}$

\section{References}

Aradau, Claudia. 2003. Trafficking in women: Human rights or human risks? Canadian Women Studies 22: 55-59. Aromaa, Kauko. 2007. Trafficking in Human Beings: Uniform definitions for better measuring and for effective counter-measures. In Measuring Human Trafficking: Complexities and Pitfalls. Edited by Ernesto U. Savona and Sonia Stefanizzi. New York: Springer. 
Augustin, Laura. 2006. The Disappearing of a Migration Category: Migrants Who Sell Sex. Journal of Ethnic and Migration Studies 32: 29-47. [CrossRef]

Barrett, Nicole A. 2010. An Exploration of Promising Practices in Response to Human Trafficking in Canada. Vancouver: International Centre for Criminal Law Reform and Criminal Justice Policy.

British Columbia Ministry of Justice. 2013. BC's Action Plan to Combat Human Trafficking, 2013-2016. Available online: http://www2.gov.bc.ca/assets/gov/law-crime-and-justice/criminal-justice/victims-of-crime/humantrafficking/about-us/action-plan.pdf (accessed on 6 June 2016).

British Columbia Ministry of Justice. 2015. BC's Action Plan to Combat Human Trafficking, Second Year Status Report, April 2014 to April 2015. Available online: http://www2.gov.bc.ca/assets/gov/law-crime-and-justice/ criminal-justice/victims-of-crime/human-trafficking/resources/2015-status-report.pdf (accessed on 8 June 2016).

British Columbia Ministry of Public Safety and Solicitor General. 2016. BC's Action Plan to Combat Human Trafficking, Third Year Status Report, April 2015 to June 2016. Available online: http://www2.gov.bc.ca/assets/gov/law-crime-and-justice/criminal-justice/victims-of-crime/humantrafficking/resources/2016-status-report.pdf (accessed on 15 October 2016).

British Columbia Ministry of Transportation and Infrastructure. 2016. BC/US Border Traveller Information. Available online: http://www.th.gov.bc.ca/ATIS/Index.htm (accessed on 27 June 2016).

Brown, Elizabeth Nolan. 2016. The Truth About the Biggest US Trafficking Story of the Year. Reason.com. September 9. Available online: http://reason.com/archives/2016/09/09/the-truth-about-us-sex-trafficking (accessed on 5 October 2016).

Brownstone, Sydney. 2015. Meet the Sex Workers Who Lawmakers Don't Believe Exist. The Stranger. Available online: http://www.thestranger.com/news/feature/2015/02/11/21689047/meet-the-sex-workerswho-lawmakers-dont-believe-exist (accessed on 8 April 2016).

Brunet-Jailly, Emmanuel. 2008. Cascadia in Comparative Perspectives: Canada-U.S. Relations and the Emergence of Cross-Border Regions. Canadian Political Science Review 2: 104-24.

Brunet-Jailly, Emmanuel. 2012. A new border? A Canadian perspective of the Canada-US border post-9/11. International Journal 67: 963-74. [CrossRef]

Canadian Department of Justice. 2016. Human Trafficking Legislation. Available online: https://www.justice.gc. ca/eng/cj-jp/tp/legis-loi.html (accessed on 3 August 2016).

Canadian Public Health Association. 2014. Sex Work in Canada: The Public Health Perspective. Ottawa: Canadian Public Health Association.

Capous Desyllas, Moshoula. 2007. A Critique of the Global Trafficking Discourse and US Policy. Journal of Sociology E Social Welfare 34: 57-79.

Canada Border Services Agency (CBSA). 2013. Entry/Exit Information System Phase I Joint Canada-United States Report. Available online: http://www.cbsa-asfc.gc.ca/btb-pdf/eeis-ponerep-sdes-rappun-eng.html (accessed on 16 July 2016).

Canada Border Services Agency (CBSA). 2016. Entry/Exit Initiative. Available online: http://www.cbsa-asfc.gc.ca/ btb-pdf/ebsiip-asfipi-eng.html (accessed on 10 October 2016).

Chuang, Janie A. 2010. Rescuing trafficking from ideological capture: Prostitution reform and anti-trafficking law and policy. University of Pennsylvania Law Review 158: 1655-728.

Citizenship and Immigration Canada Newsletter. 2016. Leniency Period for Full Implementation of Electronic Travel Authorization (eTA) System Extended Until November 9, 2016. September 21. Available online: http://www.cicnews.com/2016/09/leniency-period-implementation-eta-system-extended-november9-2016-098518.html (accessed on 17 May 2019).

Clarke, Susan. 2000. Regional and Transnational Discourse: The Politics of Ideas and Economic Development in Cascadia. International Journal of Economic Development 2: 360-78.

Corvid, Margaret. 2014. Sex Work Is Work: Exploding the Sex Trafficking Myth. New Statesman. July 7. Available online: http://www.newstatesman.com/economics/2014/07/sex-work-work-exploding-sex-trafficking-myth (accessed on 8 April 2016).

Ditmore, Melissa. 2015. Trafficking in lives: How ideology shapes policy. In Trafficking and Prostitution Reconsidered: New Perspectives on Migration, Sex Work, and Human Rights. Edited by Kamala Kempadoo, Jyoti Sanghera and Bandana Pattanaik. London: Paradigm, pp. 107-126.

Doezema, Jo. 1999. Loose women or lost women? The re-emergence of the myth of white slavery in contemporary discourses of trafficking in women. Gender Issues 18: 23-50. [CrossRef] 
Espanol, Alicia, Giuseppina Marsico, and Luca Tateo. 2018. Maintaining borders: From border guards to diplomats. Human Affairs 29: 108-26. [CrossRef]

Farrell, Amy, and Stephanie Fahy. 2009. The problem of human trafficking in the US: Public frames and policy responses. Journal of Criminal Justice 37: 617-26. [CrossRef]

Ferris, Shawna. 2015. Street Sex Work and Canadian Cities: Resisting a Dangerous Order. Edmonton: University of Alberta Press.

Finn, Rachel L., and David Wright. 2012. Unmanned aircraft systems: Surveillance, ethics and privacy in civil applications. Computer Law \& Security Review 28: 184-94.

Government of Canada. 2015. 2014-15 Report on the Beyond the Border Action Plan Horizontal Initiative. Available online: http://www.publicsafety.gc.ca/cnt/rsrcs/pblctns/dprtmntl-prfrmnc-rprt-2014-15/btb/btb-en. pdf (accessed on 15 April 2016).

Government of Canada. 2016a. Immigration and Refugee Protection Act (S.C. 2001, C. 27). Available online: http://laws.justice.gc.ca/eng/acts/i-2.5/ (accessed on 10 October 2016).

Government of Canada. 2016b. Integrated Cross-border Law Enforcement Operations Act. Available online: http://laws.justice.gc.ca/eng/acts/I-14.7/page-1.html (accessed on 15 September 2016).

Government of Canada. 2016c. Temporary Resident Permits (TRPs): Considerations Specific to Victims of Human Trafficking. Available online: http://www.cic.gc.ca/english/resources/tools/temp/permits/victim.asp (accessed on 10 October 2016).

Government of Canada. n.d. Electronic Travel Authorization (eTA). Available online: http://www.cic.gc.ca/english/ visit/eta.asp (accessed on 10 October 2016).

Gozdziak, Elzbieta M., and Elizabeth A. Collett. 2005. Research on Human Trafficking in North America: A Review of Literature. International Migration 43: 99-128. [CrossRef]

Green, Sara Jean. 2016. Large prostitution ring, Bellevue brothels shut down. The Seattle Times. January 7. Available online: http://www.seattletimes.com/seattle-news/crime/online-site-where-men-rated-prostitutesis-shut-down-charges-to-be-filed/ (accessed on 10 April 2016).

Ham, Julie, Marie Segrave, and Sharon Pickering. 2013. In the Eyes of the Beholder: Border enforcement, suspect travellers and trafficking victims. Anti-Trafficking Review 2: 51-66. [CrossRef]

Hon Chu, Sandra Ka Hon, and Rebecca Glass. 2013. Sex work law reform in Canada: Considering problems with the Nordic model. Alberta Law Review 51: 101-24.

Immigration and Refugee Protection Act (IRPA). 2001. Available online: https://laws.justice.gc.ca/eng/acts/i-2.5/ page-1.html (accessed on 17 April 2016).

Jackson, Crystal A. 2016. Framing Sex Worker Rights: How U.S. Sex Worker Rights Activists Perceive and Respond to Mainstream Anti-Sex Trafficking Advocacy. Sociological Perspectives 59: 27-45. [CrossRef]

Jeffrey, Leslie Ann. 2005. Canada and Migrant Sex Work: Challenging the 'Foreign' in Foreign Policy. Canadian Foreign Policy 12: 33-48. [CrossRef]

Kapur, Ratna. 2003. The "other" side of globalization: The legal regulation of cross-border movements. Canadian Woman Studies 22: 6-15.

Kapur, Ratna. 2015. Cross-border Movements and the Law: Renegotiating the Boundaries of Difference. In Trafficking and Prostitution Reconsidered: New Perspectives on Migration, Sex Work, and Human Rights. Edited by Kamala Kempadoo, Jyoti Sanghera and Bandana Pattanaik. London: Paradigm, pp. 25-42.

Kempadoo, Kamala. 2015. Abolitionism, Criminal Justice, and Transnational Feminism: Twenty-first-century Perspectives on Human Trafficking. In Trafficking and Prostitution Reconsidered: New Perspectives on Migration, Sex Work, and Human Rights. Edited by Kamala Kempadoo, Jyoti Sanghera and Bandana Pattanaik. London: Paradigm, pp. vii-xxxv.

Kohl-Welles, Jeanne. 2012. Landmark Washington State Accomplishments to Prevent Human Trafficking and Sexual Exploitation of Minors. Olympia: Washington State Senate.

Konrad, Victor, and Heather N. Nicol. 2011. Border Culture, the Boundary Between Canada and the United States of America, and the Advancement of Borderlands Theory. Geopolitics 16: 70-90. [CrossRef]

McAdam, Marika. 2013. Who's Who at the Border? A rights-based approach to identifying human trafficking at international borders. Anti-Trafficking Review 2: 33-49. [CrossRef]

McDonald, William F. 2014. Explaining the under-performance of the anti-human trafficking campaign: Experience from the United States and Europe. Crime Law Social Change 61: 125-38. [CrossRef] 
McIntyre, Catherine. 2015. Migrant Sex Workers Caught up in Ottawa Sting Facing Deportation, Further Exploitation. National Post. May 13. Available online: http://news.nationalpost.com/news/canada/migrant-sex-workerscaught-up-in-ottawa-sting-facing-deportation-further-exploitation-activists (accessed on 10 April 2016).

Migrant Sex Workers Project. n.d. About. Available online: http://www.migrantsexworkers.com/about.html (accessed on 11 April 2016).

Miller, Rebecca, and Sebastian Baumeister. 2013. Managing Migration: Is border control fundamental to anti-trafficking and anti-smuggling interventions? Anti-Trafficking Review 2: 15-32. [CrossRef]

Molnar, Adam, and Christopher Parsons. 2016. Unmanned Aerial Vehicles (UAVs) and Law Enforcement in Australia and Canada: Governance Through 'Privacy'in an Era of Counter-Law? In National Security, Surveillance and Terror. Cham: Palgrave Macmillan, pp. 225-47.

National Post. 2015. Judge Gives 'Psychopathic' Vancouver Pimp Longer Sentence than Crown Sought-23 Years. National Post. November 11. Available online: http://news.nationalpost.com/news/canada/judge-givespsychopathic-vancouver-pimp-longer-sentence-than-crown-sought-23-years (accessed on 21 April 2016).

Office to Combat Trafficking in Persons (OCTIP). 2014. Human Trafficking: Canada Is Not Immune. Online Training. Available online: http://www.pssg.gov.bc.ca/octiptraining/index.html (accessed on 12 May 2016).

Oxman-Martinez, Jacqueline, Jill Hanley, and Fanny Gomez. 2005. Canadian Policy on Human Trafficking: A Four-year Analysis. International Migration 43: 17-27. [CrossRef]

Paasi, Anssi. 2009. Bounded spaces in a 'borderless world': Border studies, power and the anatomy of territory. Journal of Power 2: 213-34. [CrossRef]

Perrin, Benjamin. 2010a. Trafficking in Persons and Transit Countries: A Canada-U.S. Case Study in Global Perspective. Vancouver: Metropolis BC.

Perrin, Benjamin. 2010b. Invisible Chains: Canada's Underground World of Human Trafficking. Toronto: Penguin Group.

Perrin, Benjamin. 2010c. Just Passing Through? International Legal Obligations and Policies of Transit Countries in Combating Trafficking in Persons. European Journal of Criminology 7: 11-27. [CrossRef]

Perrin, Benjamin. 2014. Oldest Profession or Oldest Oppression? Addressing Prostitution after the Supreme Court of Canada Decision in Canada v. Bedford. Ottawa: Macdonald-Laurier Institute.

Peters, Alicia W. 2015. Responding to Human Trafficking: Sex, Gender, and Culture in the Law. Philadelphia: University of Pennsylvania Press.

Pham, Lan. 2012. Ending Commercial Sexual Exploitation: A Local Coordinated Response Assessment and Strategic Framework Addressing Sex Trafficking of Minors in Seattle—King County. Seattle: Seattle Human Services Department.

Pickering, Sharon, and Julie Ham. 2013. Hot pants at the border: Sorting sex work from trafficking. British Journal of Criminology 54: 2-19. [CrossRef]

Porter, Victor. 2016. Office to Combat Trafficking in Persons, Vancouver, Canada. Personal communication, April 19.

Public Safety Canada. 2015a. Canada-United States Cross-Border Crime Forum. Available online: http://www.publicsafety.gc.ca/cnt/brdr-strtgs/crss-brdr-crm-frm-en.aspx (accessed on 18 July 2016).

Public Safety Canada. 2015b. Integrated Border Enforcement Teams. Available online: https://www.publicsafety. gc.ca/cnt/brdr-strtgs/brdr-lw-nfrcmnt/ntgrtd-brdr-nforcmnt-tms-eng.aspx (accessed on 20 July 2016).

Royal Canadian Mounted Police Human Trafficking Intelligence. 2010. Human Trafficking in Canada (Project Seclusion). Ottawa: RCMP.

Royal Canadian Mounted Police Human Trafficking National Coordination Centre. 2013. Human Trafficking for Sexual Exploitation in Canada (Project Safekeeping). Ottawa: RCMP.

Royal Canadian Mounted Police. 2015. Canada-US Shiprider. Available online: http://www.rcmp-grc.gc.ca/ibeteipf/shiprider-eng.htm (accessed on 5 June 2016).

Schwartz, Daniel. 2014. Sex Workers Like New Zealand Law, But Not Canada's New 'Nordic Model' for Prostitution. CBC News. June 5. Available online: http://www.cbc.ca/news/politics/sex-workers-like-newzealand-law-not-canada-s-new-nordic-model-for-prostitution-1.2665431 (accessed on 11 April 2016).

Sethi, Anupriya. 2007. Domestic Sex Trafficking of Indigenous Girls in Canada: Issues and Implications. First Peoples Child \& Family Review 3: 57-71.

Storer, Paul, David L. Davidson, and Laurie Trautman. 2015. Washington State's Economy in Relation to Canada and the Border. Border Policy Research Institute Publications. Available online: https://cedar.wwu.edu/bpri publications/92/ (accessed on 12 June 2016).

The Genesis Project. 2013. The Problem. Available online: http://genesisnow.org/the-problem/ (accessed on 11 April 2016). 
United Nations Protocol to Prevent, Suppress and Punish Trafficking in Person, Especially Women and Children, Supplementing the United Nations Convention against Transnational Organized Crime. 2000. Available online: https://www.ohchr.org/en/ProfessionalInterest/Pages/ProtocolTraffickingInPersons.aspx (accessed on 5 April 2016).

United States-Canada. 2006. Bi-National Assessment of Trafficking in Persons. Available online: http://www. publicsafety.gc.ca/cnt/rsrcs/pblctns/archive-ssssmnt-trffckng-prsns/index-en.aspx (accessed on 5 April 2016).

US Citizenship and Immigration Services. 2011. Victims of Human Trafficking: T Non-immigrant Status. Available online: https://www.uscis.gov/humanitarian/victims-human-trafficking-other-crimes/victimshuman-trafficking-t-nonimmigrant-status (accessed on 15 May 2016).

US Customs and Border Protection. 2016. Electronic System for Travel Authorization. Available online: https://www.cbp.gov/travel/international-visitors/esta (accessed on 4 June 2016).

US Department of Homeland Security. 2015. Human Trafficking Laws and Regulations. Available online: https://www.dhs.gov/human-trafficking-laws-regulations (accessed on 16 April 2016).

US Department of Justice. 2015. Citizen's Guide to US Federal Law on the Prostitution of Children. Available online: https://www.justice.gov/criminal-ceos/citizens-guide-us-federal-law-prostitution-children (accessed on 16 April 2016).

US Department of State. 2000. Victims of Trafficking and Violence Protection Act of 2000. Available online: http://www.state.gov/j/tip/laws/ (accessed on 5 April 2016).

US Department of State. 2016. Trafficking in Persons Report 2016. Available online: http://www.state.gov/j/tip/rls/ tiprpt/2016/ (accessed on 4 April 2016).

Washington State Legislature. 2013. RCW 9A.40.100. Available online: http://apps.leg.wa.gov/rcw/default.aspx? cite=9A.40.100 (accessed on 10 April 2016).

Washington State Legislature. 2015. SR 8644-2015-16. Available online: https://app.leg.wa.gov/billsummary? BillNumber $=8644 \&$ Year=2015\&Initiative $=$ False\#documentSection (accessed on 10 April 2016).

Washington State Task Force against the Trafficking in Persons. 2008. Report to the Legislature. Olympia: Washington State Department of Community, Trade and Economic Development.

Weitzer, Ronald. 2007. The Social Construction of Sex Trafficking: Ideology and Institutionalization of a Moral Crusade. Politics and Society 35: 447-75. [CrossRef]

Wetmore, Jennifer M. 2003. The New T Visa: Is the Higher Extreme Hardship Standard Too High for Bona Fide Trafficking Victims? New England Journal of International and Comparative Law 9: 159-76.

Williamson, Hugh R. 2009. Illegal Immigration to Canada by Sea: An Integrated Marine Security Response. In Understanding and Strengthening European Union-Canada Relations in Law of the Sea and Ocean Governance. Edited by Timo Koivurova, Aldo Chircop, Erik Franckx, Erik J. Molenaar and David L. VanderZwaag. Rovaniemi: University of Lapland Printing Centre.

Young, Becki. 1998. Trafficking of humans across United States borders: How United States laws can be used to punish traffickers and protect victims. Georgetown Immigration Law Journal 13: 73-104.

(C) 2019 by the authors. Licensee MDPI, Basel, Switzerland. This article is an open access article distributed under the terms and conditions of the Creative Commons Attribution (CC BY) license (http://creativecommons.org/licenses/by/4.0/). 